УДК 339.9

DOI: 10.35340/2308-104X.2019.83-2-13

\section{МОДЕЛЮВАННЯ \\ СТРУКТУРНОЇ \\ ТРАНСФОРМАЦІЇ ЕКОНОМІКИ \\ КРАЇНИ В УМОВАХ \\ ГЛОБАЛІЗАЦІЙНИХ ВИКЛИКІВ}

\author{
MODELING OF STRUCTURAL \\ TRANSFORMATION OF THE \\ ECONOMY OF THE COUNTRY \\ IN THE CONDITIONS OF \\ GLOBALIZATION CHALLENGES
}

УСИК І. О., здобувач, Донецький національний університет імені В. Стуса, м. Вінниця
USIK I.,

Applicant, Donetsk National

University named after V. Stus, Vinnitsa, Ukraine

У статті розкрито основи моделювання структурної трансформації економіки краӥни в умовах глобалізаційних викликів. Побудована система економетричних моделей розвитку економіки краӥни за такими видами економічної діяльності: промисловість, сільське господарство, будівництво, транспорт та зв'язок та сфера послуг. Формування системи економетричних моделей за кожним видом економічної діяльності здійснювалося на основі даних за 2001-2018 рр. за такими параметрами: доходи бюджету краӥни; інвестиції в основний капітал; обсяг основних фондів в галузі виробництва; чисельність зайнятих; випуск товарів та послуг за галуззю виробництва. На основі системи економетричних моделей розвитку економіки краӥни здійснено прогнозування структури економіки на 2019-2022 рр., проведена оцінка структурної трансформації та виявлено, щуо в економіці Украйни з 2010 р. намітилася тенденція до збільшення частки валового випуску в сфері послуг. Прогнозна структура економіки краӥни дозволяє розробити заходи державної політики щодо стабілізащії економіки від наслідків можливої структурної трансформаиії.

Ключові слова: моделювання, структурна трансформачія, види економічної діяльності, прогноз.

B статье раскрыты основы моделирования структурной трансформации экономики страны в условиях глобализачионных вызовов. Сформирована система эконометрических моделей развития экономики страны по следующим видам экономической деятельности: промышленность, сельское хозяйство, строительство, транспорт и связь и сфера услуг. Формирование системы эконометрических моделей по каждому виду экономической деятельности осуществлялось на основе данных за 2001-2018 г2. по следуюшим параметрам: доходы бюджета страны; инвестищии в основной капитал; объем основных фондов в отрасли; численность занятых; выпуск товаров и услуг по отрасли. На основе системь эконометрических моделей развития экономики страны, осуществлено прогнозирование структуры экономики на 2019-2022 г2., Проведена оченка структурной трансформации и выявлено, что в 
экономике Украины с 2010 г. наметилась тенденщия к увеличению доли валового выпуска в сфере услуг. Прогнозная структура экономики странь позволяет разработать мероприятия государственной политики по стабилизации экономики от последствий возможной структурной трансформаџчи.

Ключевые слова: моделирование, структурная трансформация, виды экономической деятельности, прогноз.

The article describes the basics of modeling of the structural transformation of the country's economy in the context of globalization challenges. A system of econometric models of the country's economy development based on the following types of economic activity: industry, agriculture, construction, transport, communications and services. The formation of a system of econometric models for each type of economic activity was carried out on the basis of data for 2001-2018 according to the following parameters: budget revenues of the country; investment in fixed assets; the volume of fixed assets in the field of production; number to take; production of goods and services for the production industry. On the basis of the system of econometric models of the country's economy development, the forecasting of the structure of the economy for 2019-2022 was carried out, an assessment of the structural transformation was carried out, and it was found that in the Ukrainian economy since 2010 there was a tendency to increase the share of gross output in the service sector. The predicted structure of the country's economy allows developing state policy measures to stabilize the economy from the effects of a possible structural transformation.

Keywords: modeling, structural transformation, types of economic activity, forecast.

Постановка проблеми. Дослідження країни як соціально-економічної

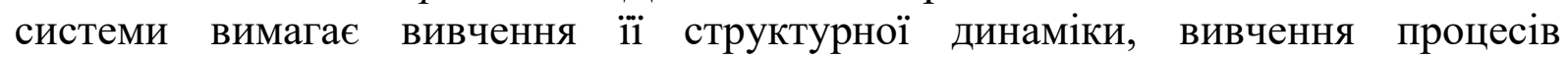
державного регулювання, а також аналізу еволюції галузевої структури, нововведень [1].

Аналіз останніх досліджень $i$ публікацій. Теоретичним і прикладним аспектам дослідження структурної трансформації присвячені наукові праці таких учених, як: В. М. Гейця, А. Картер, Ю. В. Кіндзерського, П. Кларка, Р. Стоуна, В. Фішера, Р. Фріша, К. Ченері, Л. І. Федулової та багатьох інших [1-3]. Низка досліджень, пов'язаних з економіко-математичним моделюванням економічних процесів, належить таким авторам, як А. В. Череп, Т. В. Гринько, О. А. Гаврилова, С. І. Войнова, М. С. Яворський.

Однак і досі невирішеним залишається питання щодо обгрунтування цілісної системи показників-факторів, які слід включити до економікоматематичної моделі структурних трансформацій економіки країни, яка може служити інформаційною основою для прийняття зважених управлінських рішень щодо напрямів структурних змін в економіці.

Метою дослідження є обгрунтування моделювання структурної трансформації економіки країни в умовах глобалізаційних викликів.

Виклад основного матеріалу дослідження. Прогнозування галузевої структури на основі індексного методу здійснити складно, воно можливе на основі математичного моделювання. 
В. В. Вітлінський визначає моделювання як «основний специфічний метод науки, що застосовується для аналізу та синтезу систем управління, а також особливий пізнавальний спосіб, коли суб'єкт дослідження замість безпосереднього досліджуваного об'єкта пізнання обирає чи створює подібний до нього допоміжний об'єкт - образ чи модель, досліджує його, а отримані нові знання переносить на об'єкт оригінал» [4, с. 10].

3 ним погоджуються М. П. Власов та П. Д. Шимко і відмічають, що моделювання $€$ потужним знаряддям наукового пізнання i вирішення практичних задач, який широко використовується як в науці, так і в багатьох ланках виробничої діяльності людини [5, с. 384].

Отже, моделювання дозволяє здійснити ефективний аналіз ситуації i прийняти доцільне рішення [5, с. 8].

Широке поширення в практиці прогнозування отримали методи екстраполяції, засновані на виявленні тенденцій досліджуваних показників [6]. Прогноз здійснюється на основі перенесення на майбутнє вихідного стану показника за умовою, що досліджуваний процес, що характеризується обраним показником, буде відчувати ті ж зовнішні впливи. Екстраполяційний підхід застосовується при прогнозуванні показників виробничого потенціалу країн, що мають стійке економічне зростання. Зміни ВВП України за останні роки показали нестійкість економічного зростання, що полягає в спаді, а потім деякому його збільшенні. Тому використання екстраполяційних методів може дати прогнозні значення стану досліджуваних процесів зі значною похибкою. Пропонована модель прогнозування економіки країни представляє собою систему економетричних рівнянь вигляду (1):

$$
\left\{\begin{array}{l}
D_{t}=\alpha+\beta t+\gamma t^{2} \\
I_{i, t}=\alpha+\beta I_{i, t-1}+\gamma D_{t} \\
F_{i, t}=\alpha+\beta F_{i, t-1}+\gamma I_{i, t} \\
Z_{i, t}=\alpha+\beta t \\
V_{i, t}=\alpha+\beta F_{i, t-1}+\gamma D Z_{i, t}
\end{array},\right.
$$

де $D_{t}$ - доходи бюджету країни;

$\mathrm{I}_{i, t}-$ інвестиції в основний капітал;

$F_{i, t}$ - обсяг основних фондів в і-тій галузі виробництва;

$Z_{i, t}-$ чисельність зайнятих в в і-тій галузі виробництва;

$V_{i, t}-$ випуск товарів та послуг за і-тою галуззю виробництва.

В якості факторів, що визначають валовий випуск, обрані показники, які $\epsilon$ найбільш значущими для економіки країни.

Вже згадана нами модель $є$ системою взаємопов'язаних рівнянь. При прогнозуванні обсягів інвестицій в основний капітал екзогенними змінними $\epsilon$ інвестиції в основний капітал за попередній період і доходи бюджету країни. В свою чергу прогноз основних фондів проводиться на основі значень основних фондів та обсягів інвестицій в основний капітал за попередній період. Поряд 3 основними фондами при прогнозуванні випуску товарів та послуг 
використовується чисельність зайнятих в економіці, що розраховується на основі полінома другого ступеня.

«Стохастичні залежності в яких враховують вплив декількох факторів на результативну ознаку описують засобами кореляційного аналізу. Залежності представляють у вигляді аналітичних рівнянь (функцій)» [7, с. 10].

Для опису залежності доходів зведеного бюджету України в 2001-2018 pp. скористуємося можливостями пакету прикладних програм Microsoft Office, зокрема можливості моделювання стохастичних взаємозв'язків у табличному редакторі Microsoft Excel.

Дослідимо динаміку доходів зведеного бюджету України в 2001-2018 pp. i сформуємо поліном (рис. 1).

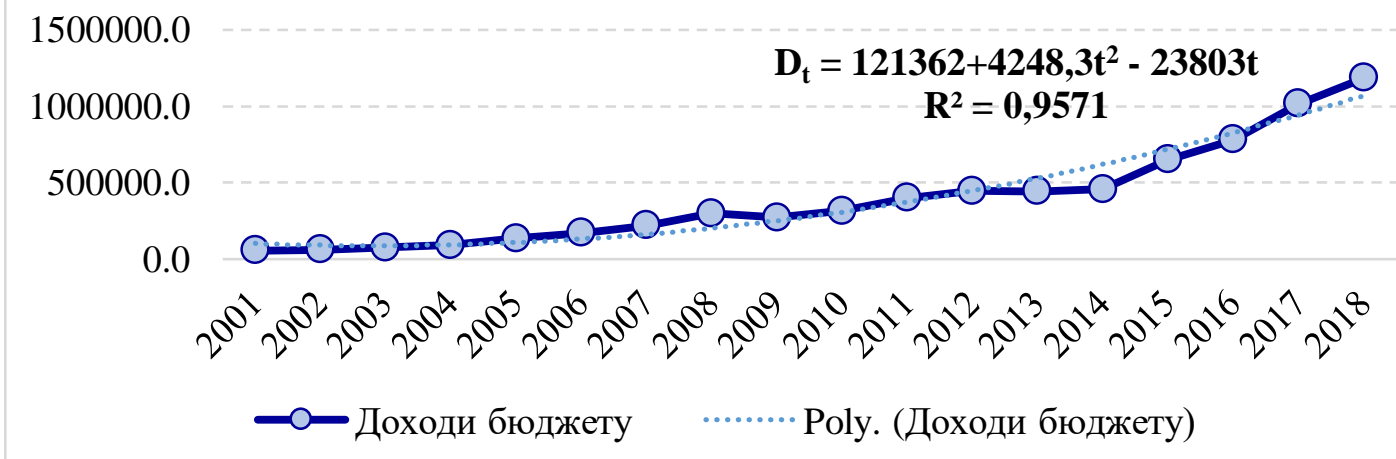

Рис. 1. Динаміка доходів зведеного бюджету України в 2001-2018 pр., млн грн

Джерело: складено автором за даними [8]

Результати, наведені на рис. 1 свідчать про суттєвий вплив часу на рівень доходів зведеного бюджету України $R^{2}=0,9571$.

Таким чином, регресійне рівняння залежності доходів зведеного бюджету України буде мати вигляд:

$$
D_{t}=121362+4248,3 t^{2}-23803 t
$$

Розрахунки за промисловістю України проведено за даними 2001-2018 рр.

Дослідимо взаємозалежність між інвестиціями в основний капітал в промисловість України в 2001-2018 рр. та сумами доходів зведеного бюджету (рис. 2). Використовуючи графічні можливості табличного редактора Microsoft Excel побудуємо регресійне рівняння залежності суми інвестицій в основний капітал за промисловістю України виключно від суми доходів зведеного бюджету.

Накладемо на лінію розподілу інвестицій в основний капітал в промисловість України в 2001-2018 рр. та сумами доходів зведеного бюджету країни лінію регресії, підібравши такий іiї вигляд, що відповідає максимальному значенню коефіцієнта детермінації (рис. 2). 


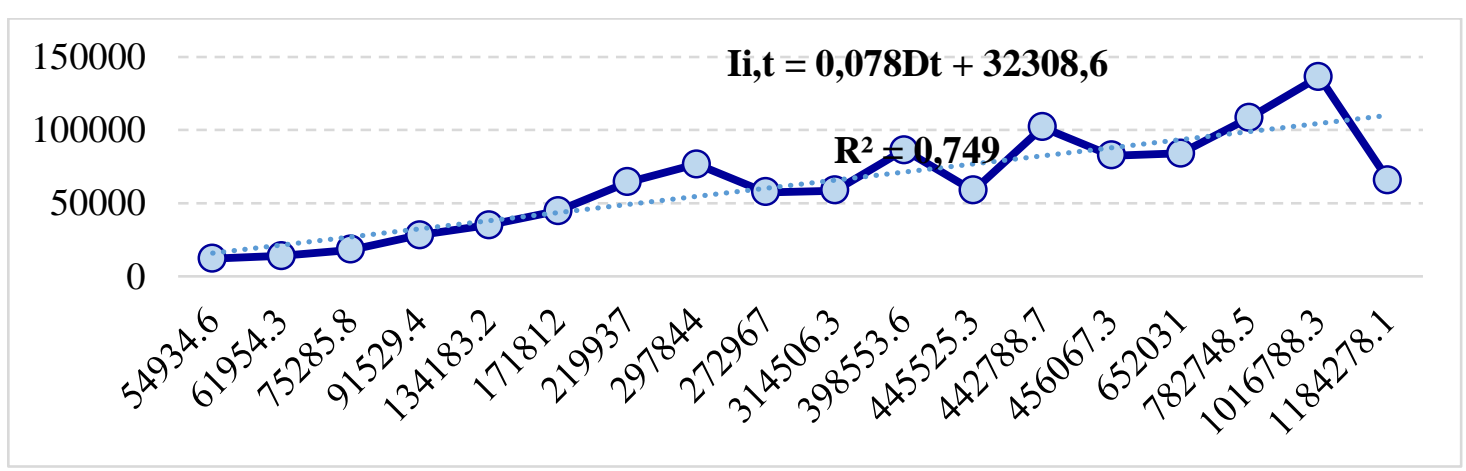

Рис. 2. Залежність суми інвестицій в основний капітал промисловості від доходів зведеного бюджету України за 2001-2018 рр., млн грн Джерело: складено та розраховано автором за даними [8]

Отримуємо рівняння інвестицій в основний капітал промисловості у вигляді лінійної функції:

$$
I_{i, t}=0,078 D t+32308,6
$$

Отримане рівняння регресії зрівноважує коливання та визначає основну тенденцію з коефіцієнтом множинної детермінації, що дорівнює $R^{2}=0,7491$.

Отже, можливо узагальнити, що у випадку збереження попередніх умов розвитку, на 74,91\% варіація інвестицій в основний капітал промисловості України в 2001-2018 рр. може бути представлена у вигляді лінійної функції залежності від суми доходів зведеного бюджету.

Використовуючи метод найменших квадратів для множинної регресії отримані такі значення невідомих параметрів рівняння вартості основних фондів промисловості України від суми доходів інвестицій в основний капітал промисловості та потоку вартості основних фондів промисловості на період t-1:

$$
F_{i, t}=237957,4+0,502 I_{i, t}+0,899 F_{i, t-1} \text {, }
$$

Перевірка моделі на адекватність дозволила обчислити певні іiі характеристики (табл. 1).

Таблиця 1

Характеристики моделі

\begin{tabular}{|l|c|l|c|}
\hline \multicolumn{1}{|c|}{ Характеристики моделі } & Значення & \multicolumn{1}{|c|}{ Характеристики моделі } & Значення \\
\hline $\begin{array}{l}\text { Коефіцієнт множинної } \\
\text { кореляції }\left(R_{x y}\right)\end{array}$ & 0,875 & $\begin{array}{l}\text { Парні коефіцієнти кореляції: } \\
\text { в т.ч. }\end{array}$ & 0,765 \\
\hline Коефіцієнт детермінації $(d)$ & 0,765 & $\begin{array}{l}\text { 1) Інвестиції в основний капітал } \\
\text { промисловості }\left(r_{x l y}\right)\end{array}$ & 0,875 \\
\hline $\begin{array}{l}\text { F-критерій розрахунковий } \\
(F р о з р)\end{array}$ & 55,28 & $\begin{array}{l}\text { 2) Потік вартості основних фондів } \\
\text { промисловості на період t-1 }\left(r_{x 2 y}\right)\end{array}$ & \\
\hline
\end{tabular}


Дослідимо динаміку зміни чисельності зайнятих в промисловості України за 2001-2018 pp. Використовуючи графічні можливості табличного редактора Microsoft Excel побудуємо регресійне рівняння чисельності зайнятих в промисловості України, що відповідає максимальному значенню коефіцієнта детермінації (рис. 3).

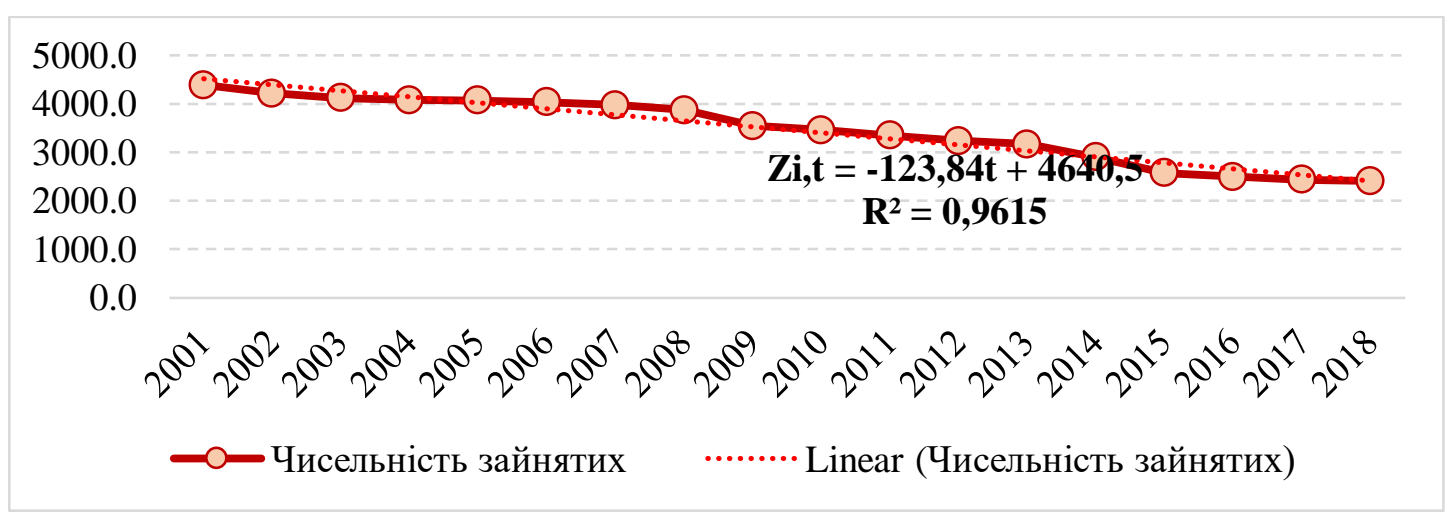

Рис. 3. Динаміка зайнятих в промисловості України в 2001-2017 pp., тис. осіб

Джерело: складено та розраховано автором за даними [8]

Отримуємо рівняння чисельності зайнятих в сільському господарстві у вигляді лінійної функції:

$$
Z_{i, t}=4640,5-123,84 \mathrm{t}
$$

Отримане рівняння регресії зрівноважує коливання та визначає основну тенденцію з коефіцієнтом множинної детермінації, що дорівнює $R^{2}=0,9615$.

Отже, можливо узагальнити, що у випадку збереження попередніх умов розвитку, на 96,15\% варіація чисельності зайнятих в промисловість України в 2001-2018 рр. може бути представлена у вигляді лінійної функції.

За допомогою Microsoft Excel побудуємо регресійне рівняння залежності вартості валового випуск товарів та послуг у промисловості України від суми вартості основних фондів промисловості України та чисельності зайнятих в промисловості.

У середовищі MS Excel проведено регресійний аналіз впливу суми вартості основних фондів промисловості України та чисельності зайнятих в промисловості на вартість валового випуску промисловості України за 2001-2017 рр. Отже, можна зробити висновок, що найбільш повно описує залежність між досліджуваними чинниками факторна модель, що має вигляд:

$$
V_{i, t}=5800427-0,203 F_{i, t}-1290,89 Z_{i, t},
$$

Коефіцієнти рівняння показують кількісний вплив кожного фактора на результативний показник при незмінності інших. Вартість випуску товарів та послуг у промисловості України при збільшення вартості основних фондів 
промисловості України на 1 пункт зменшиться на 0,203 пункти, при збільшенні чисельності зайнятих в промисловості на 1 пункт зменшиться на 1290,89 пункти.

Коефіцієнт детермінації для лінійної моделі показує, що варіація випуску товарів та послуг у промисловості України на 92,58\% визначається варіацією досліджуваних факторів.

Таким чином, згідно 3 обчисленими характеристиками (коефіцієнти детермінації, кореляції, критерії Фішера та Стьюдента), які використані для оцінювання достовірності моделі, можна зробити висновок, що побудована нами модель відбиває тісний зв'язок між валовим випуском товарів і послуг у промисловості України та вартістю основних фондів промисловості i чисельністю зайнятих в промисловості.

Отже, у результаті розрахунків для промисловості України отримана система рівнянь:

$$
\left\{\begin{array}{l}
D_{t}=121362+4248,3 t^{2}-23803 t \\
I_{i, t}=0,078 D t+32308,6 \\
F_{i, t}=237957,4+0,502 I_{i, t}+0,899 F_{i, t-1} \\
Z_{i, t}=4640,5-123,84 \mathrm{t} \\
V_{i, t}=5800427-0,203 F_{i, t}-1290,89 Z_{i, t}
\end{array}\right.
$$

де $D_{t}$ - доходи бюджету країни;

$\mathrm{I}_{t}-$ інвестиції в основний капітал промисловості;

$F_{i, t}$ - обсяг основних фондів промисловості;

$Z_{i, t}$ - чисельність зайнятих у промисловості;

$V_{i, t}-$ випуск товарів та послуг у промисловості.

Аналогічні розрахунки проведені щодо розробки системи економетричних моделей за такими видами діяльності в Україні як сільське господарство, будівництво, транспорт та зв'язок:

сільське господарство:

$$
\left\{\begin{array}{l}
D_{t}=121362+4248,3 t^{2}-23803 t \\
I_{i, t}=-4595,7+0,057 \mathrm{D}_{t} \\
F_{i, t}=61412,7+3,13 I_{i, t}+0,174 F_{i, t-1} \\
Z_{i, t}=4237,4-85,74 \mathrm{t} \\
V_{i, t}=331473-2,39 F_{i, t}-113,69 Z_{i, t}
\end{array}\right.
$$

будівництво:

$$
\left\{\begin{array}{l}
D_{t}=121362+4248,3 t^{2}-23803 t \\
I_{i, t}=0,051 t-1114,2 \\
F_{i, t}=55757,1-0,875 I_{i, t}+0,633 F_{i, t-1} \\
Z_{i, t}=798,12-3,1684 \mathrm{t} 2+44,884 \mathrm{t} \\
V_{i, t}=509138+0,704 F_{i, t}-511,168 Z_{i, t}
\end{array} .\right.
$$


транспорт та зв’язок:

$$
\left\{\begin{array}{l}
D_{t}=121362+4248,3 t^{2}-23803 t \\
I_{i, t}=11,166 \mathrm{D}_{t}^{4}-379,58 \mathrm{D}_{t}^{3}+3907,6 \mathrm{D}_{t}^{2} \\
-10612 \mathrm{D}_{t}+1429 \\
F_{i, t}=-375268+63,973 I_{i, t}+0,621 F_{i, t-1} \\
Z_{i, t}=-3,1684 \mathrm{t}^{2}+44,884 \mathrm{t}+798,1 \\
V_{i, t}=911319+0,005 F_{i, t}-585,866 Z_{i, t}
\end{array} .\right.
$$

сфера послуг:

$$
\left\{\begin{array}{l}
D_{t}=121362+4248,3 t^{2}-23803 t \\
I_{i, t}=51,317 \mathrm{D}_{t}^{4}-1715,7 \mathrm{D}_{t}^{3}+18322 \mathrm{D}_{t}^{2}-61414 \mathrm{D}_{t}+63105 \\
F_{i, t}=155795-0,64 I_{i, t}+1,2 F_{i, t-1} \\
Z i, t=1,332 \mathrm{t} 3-63,345 \mathrm{t} 2+778,72 \mathrm{t}+8147,9 \\
V_{i, t}=-537132+0,833 F_{i, t}+47,747 Z_{i, t}
\end{array}\right.
$$

Отримані моделі адекватні за розглянутими параметрами. У табл. 2 представлені параметри, що характеризують якість отриманих моделей: $\mathrm{R}^{2}-$ коефіцієнт детермінації; F - фактичне значення критерія Фішера.

Таблиця 2

\begin{tabular}{|c|c|c|c|c|c|}
\hline \multirow{2}{*}{ Критеріï } & \multicolumn{5}{|c|}{ Показники } \\
\hline & $D_{t}$ & $I_{i, t}$ & $F_{i, t}$ & $Z_{i, t}$ & $V_{i, t}$ \\
\hline \multicolumn{6}{|c|}{ Промисловість } \\
\hline$R^{2}$ & 0,9571 & 0,7463 & 0,7648 & 0,9615 & 0,9258 \\
\hline $\mathrm{F}$ & 379,27 & 50,01 & 55,28 & 424,56 & 212,11 \\
\hline \multicolumn{6}{|c|}{ Сільське господарство } \\
\hline$R^{2}$ & 0,9571 & 0,9290 & 0,9040 & 0,8921 & 0,9548 \\
\hline $\mathrm{F}$ & 379,27 & 222,44 & 160,08 & 140,55 & 359,11 \\
\hline \multicolumn{6}{|c|}{ Будівництво } \\
\hline$R^{2}$ & 0,9571 & 0,9571 & 0,7496 & 0,4937 & 0,7673 \\
\hline $\mathrm{F}$ & 379,27 & 379,27 & 50,89 & 16,58 & 56,06 \\
\hline \multicolumn{6}{|c|}{ Транспорт і зв'язок } \\
\hline$R^{2}$ & 0,9571 & 0,8539 & 0,4400 & 0,8489 & 0,7113 \\
\hline $\mathrm{F}$ & 379,27 & 99,36 & 13,36 & 95,51 & 41,88 \\
\hline \multicolumn{6}{|c|}{ Сфера послуг } \\
\hline$R^{2}$ & 0,9571 & 0,9361 & 0,9072 & 0,7131 & 0,9520 \\
\hline $\mathrm{F}$ & 379,27 & 249,04 & 166,19 & 42,25 & 337,17 \\
\hline
\end{tabular}

Параметри перевірки якості моделей

Джерело: складено та розраховано автором

На основі отриманих моделей проведений прогноз досліджуваних показників. У таблиці 3 представлена динаміка зміни досліджених показників та їхній прогноз до 2022 р. За результатами прогнозних значень спостерігається збільшення випуску товарів та послуг в ринкових цінах показників в 2022 р. порівняно з 2001 р. в цілому за економікою в 17,3 рази, промисловості - в 13 разів, сільському господарстві - майже в 15 разів, будівництві - в 16 разів, на 
транспорті і зв'язку - в 26,6 рази, послуги - в 22,7 рази.

Якщо порівняти прогнозні значення 3 останнім фактичним періодом 2018 р., то за результатами прогнозних значень спостерігається збільшення випуску товарів та послуг в ринкових цінах показників в 2022 р. порівняно 3 2001 р. в цілому за економікою на 24,1\%, промисловості - на 19,1\%, сільському господарстві - майже на 29,9\%, будівництві - на 6,4\%, на транспорті і зв'язку на 96,6\%, послуги - на 17,8\%.

На основі отриманих прогнозних значень випуску товарів та послуг в ринкових цінах за видами економічної діяльності представлено структуру економіки України за 2001-2022 рр. (табл. 4).

Таблиця 4

Структура випуску товарів та послуг в ринкових цінах за видами економічної діяльності України за 2001-2022 рр., млн грн

\begin{tabular}{|c|c|c|c|c|c|}
\hline Роки & $\begin{array}{c}\text { Промисло- } \\
\text { вість }\end{array}$ & $\begin{array}{c}\text { Сільське } \\
\text { господарство }\end{array}$ & Будівництво & $\begin{array}{c}\text { Транспорт } \\
\text { та зв'язок }\end{array}$ & Послуги \\
\hline 2001 & 44,5 & 13,4 & 4,8 & 6,7 & 30,7 \\
\hline 2002 & 44,3 & 12,3 & 4,6 & 7,0 & 31,8 \\
\hline 2003 & 44,5 & 10,2 & 5,1 & 7,5 & 32,7 \\
\hline 2004 & 44,6 & 9,9 & 5,6 & 7,0 & 33,0 \\
\hline 2005 & 44,0 & 8,8 & 5,5 & 6,8 & 34,9 \\
\hline 2006 & 42,5 & 7,6 & 6,4 & 6,7 & 36,8 \\
\hline 2007 & 41,4 & 6,6 & 7,1 & 6,4 & 38,5 \\
\hline 2008 & 40,6 & 6,9 & 6,7 & 6,1 & 39,7 \\
\hline 2009 & 37,4 & 7,4 & 5,4 & 6,9 & 42,8 \\
\hline 2010 & 40,1 & 7,6 & 5,3 & 6,5 & 40,7 \\
\hline 2011 & 40,3 & 8,3 & 5,2 & 6,8 & 39,3 \\
\hline 2012 & 38,4 & 8,1 & 5,5 & 6,6 & 41,4 \\
\hline 2013 & 35,9 & 9,4 & 5,1 & 6,7 & 42,8 \\
\hline 2014 & 36,0 & 10,7 & 4,6 & 6,1 & 42,6 \\
\hline 2015 & 35,0 & 12,4 & 4,2 & 6,6 & 41,8 \\
\hline 2016 & 36,1 & 12,1 & 4,4 & 6,3 & 41,1 \\
\hline 2017 & 36,2 & 10,8 & 4,9 & 6,3 & 41,8 \\
\hline 2018 & 34,9 & 10,9 & 5,2 & 6,5 & 42,5 \\
\hline 2019 & 35,3 & 10,5 & 4,3 & 9,5 & 40,4 \\
\hline 2020 & 34,2 & 10,7 & 4,3 & 9,5 & 41,4 \\
\hline 2021 & 33,5 & 11,0 & 4,3 & 9,8 & 41,4 \\
\hline 2022 & 33,5 & 11,4 & 4,4 & 10,3 & 40,4 \\
\hline
\end{tabular}

Джерело: складено та розраховано автором на основі [8] 
Таблиця 3

Вихідні та прогнозні данні суми випуску товарів та послуг в ринкових цінах та вклад видів економічної діяльності України за 2001-2022 рр., млн грн

\begin{tabular}{|c|c|c|c|c|c|c|}
\hline Роки & $\begin{array}{c}\text { Випуск товарів } \\
\text { та послуг }\end{array}$ & Промисловість & $\begin{array}{c}\text { Сільське } \\
\text { господарство }\end{array}$ & Будівництво & $\begin{array}{c}\text { Транспорт та } \\
\text { зв'язок }\end{array}$ & Послуги \\
\hline 2001 & 346040 & 222045,0 & 66788,0 & 23792,0 & 33415,0 & 153051,0 \\
\hline 2002 & 371648 & 241694,0 & 66902,0 & 25065,0 & 37987,0 & 173372,0 \\
\hline 2003 & 438183 & 289599,0 & 66602,0 & 33440,0 & 48542,0 & 213238,0 \\
\hline 2004 & 584736 & 388838,0 & 86216,0 & 48808,0 & 60874,0 & 287596,0 \\
\hline 2005 & 708710 & 479402,0 & 95520,0 & 59976,0 & 73812,0 & 379672,0 \\
\hline 2006 & 822433 & 553519,0 & 99154,0 & 82667,0 & 87093,0 & 478809,0 \\
\hline 2007 & 1055403 & 710209,0 & 114031,0 & 121864,0 & 109299,0 & 661255,0 \\
\hline 2008 & 1373740 & 925453,0 & 157208,0 & 151519,0 & 139560,0 & 903072,0 \\
\hline 2009 & 1222358 & 799496,0 & 159187,0 & 115952,0 & 147723,0 & 915478,0 \\
\hline 2010 & 1488111 & 1004608,0 & 189373,0 & 132351,0 & 161779,0 & 1019328,0 \\
\hline 2011 & 1846956 & 1228141,0 & 253485,0 & 159378,0 & 205952,0 & 1198285,0 \\
\hline 2012 & 1894406 & 1242188,0 & 261707,0 & 178225,0 & 212286,0 & 1339768,0 \\
\hline 2013 & 1865984 & 1171899,0 & 306998,0 & 167196,0 & 219891,0 & 1394569,0 \\
\hline 2014 & 2041340 & 1280275,0 & 381227,0 & 162551,0 & 217287,0 & 1516883,0 \\
\hline 2015 & 2612026 & 1569009,0 & 558788,0 & 188595,0 & 295634,0 & 1876372,0 \\
\hline 2016 & 3192626 & 1954792,0 & 655569,0 & 240327,0 & 341938,0 & 2227807,0 \\
\hline 2017 & 3907571 & 2433239,0 & 727352,0 & 326496,0 & 420484,0 & 2812147,0 \\
\hline 2018 & 3991496 & 2423918,7 & 757896,0 & 357896,0 & 451785,0 & 2954256,0 \\
\hline 2019 & 4080634 & 2414704,1 & 719067,3 & 296272,7 & 649903,4 & 2770056,3 \\
\hline 2020 & 4415398 & 2573003,6 & 805653,0 & 320184,0 & 715436,9 & 3114886,8 \\
\hline 2021 & 4767737 & 2730265,9 & 893221,2 & 348637,1 & 794218,4 & 3373388,4 \\
\hline 2022 & 5141990 & 2886528,0 & 984601,9 & 380888,6 & 888403,2 & 3479211,0 \\
\hline $\begin{array}{c}\text { Коефіцієнт } \\
\text { зростання } 2022 \text { до } \\
\text { 2001, рази }\end{array}$ & 17,3 & 13,0 & 14,7 & 16,0 & 26,6 & 22,7 \\
\hline $\begin{array}{l}\text { Темп зростання } \\
2022 \text { до 2018, \% }\end{array}$ & 124,1 & 119,1 & 129,9 & 106,4 & 196,6 & 117,8 \\
\hline
\end{tabular}

Джерело: складено та розраховано автором на основі [8] 
Як видно 3 представлених в таблиці 4 даних, галузева структура економіки України майже не змінилася і не зазнає суттєвих змін в 2019-2022 рр.

Розподіл узагальнюючих індексів за 2001-2022 рр. наведений в табл. 5.

Таблиця 5

Узагальнюючі індекси за 2001-2022 рр.

\begin{tabular}{|c|c|c|c|}
\hline Періоди & К. Гатєва & В.М. Рябцева & А. Салаї \\
\hline $2002-2001$ & 0,0204 & 0,0145 & 0,0242 \\
\hline $2003-2002$ & 0,0295 & 0,0208 & 0,0503 \\
\hline $2004-2003$ & 0,0098 & 0,0069 & 0,0254 \\
\hline $2005-2004$ & 0,0282 & 0,0199 & 0,0304 \\
\hline $2006-2005$ & 0,0347 & 0,0246 & 0,0471 \\
\hline $2007-2006$ & 0,0299 & 0,0212 & 0,0427 \\
\hline $2008-2007$ & 0,0180 & 0,0127 & 0,0203 \\
\hline $2009-2008$ & 0,0584 & 0,0414 & 0,0610 \\
\hline $2010-2009$ & 0,0423 & 0,0299 & 0,0256 \\
\hline $2011-2010$ & 0,0192 & 0,0136 & 0,0253 \\
\hline $2012-2011$ & 0,0351 & 0,0248 & 0,0217 \\
\hline $2013-2012$ & 0,0385 & 0,0273 & 0,0414 \\
\hline $2014-2013$ & 0,0192 & 0,0136 & 0,0446 \\
\hline $2015-2014$ & 0,0281 & 0,0199 & 0,0426 \\
\hline $2016-2015$ & 0,0176 & 0,0125 & 0,0185 \\
\hline $2017-2016$ & 0,0192 & 0,0136 & 0,0325 \\
\hline $2018-2017$ & 0,0191 & 0,0135 & 0,0182 \\
\hline $2019-2018$ & 0,0475 & 0,0336 & 0,0932 \\
\hline $2020-2019$ & 0,0183 & 0,0129 & 0,0103 \\
\hline $2021-2020$ & 0,0094 & 0,0066 & 0,0093 \\
\hline $2022-2021$ & 0,0167 & 0,0118 & 0,0177 \\
\hline $2022-2001$ & 0,0376 & 0,1384 & 0,1352 \\
\hline
\end{tabular}

Джерело: складено та розраховано автором на основі [8]

У 2022 р. в порівнянні з 2001 р. розподіл індексів відносно структурних невідповідностей наступний: індекс структурних зрушень А. Салаї - 0,1352; інтегральний коефіцієнт К. Гатєва - 0,0376; критерій В. М. Рябцева - 0,1384.

Висновки і перспективи подальших досліджень. Отже, до 2009 р. в Україні основний внесок у випуск товарів та послуг в ринкових цінах здійснює промисловість, а починаючи 32010 р. - сфера послуг. Однак позитивним $\epsilon$ та обставини, що збільшується частка в випуску товарів та послуг переробних виробництв (збільшення вдесятеро в 2018 р. порівняно із 2001 р.).

Таким чином, за аналізований період 2001-2022 рр. відбулися наступні зміни в моделі розвитку економіки структурі України:

- спостерігається невелика зміна в структурі економіки за видами економічної діяльності;

- загальне співвідношення питомої ваги в випуску товарів та послуг в ринкових цінах за видами економічної діяльності зберігається;

- структурні зрушення галузевої структури змінилися незначно. 
На основі прогнозних даних структурної трансформації моделі розвитку економіки країна розробляє заходи державної політики щодо стабілізації економіки від наслідків можливої структурної трансформації. Розробка рекомендацій щодо стабілізації економіки від наслідків структурної трансформації і стануть об'єктом подальших досліджень.

Лimepamypa:

1. Геєць В. М., Шинкарук Л. В., Артьомова Т. І. Структурні зміни та економічний розвиток України. К.: Експрес, 2011. 696 с.

2. Кіндзерський Ю. В. Промисловість України: стратегія і політика структурно-технологічної модернізації. К., 2013. 536 с.

3. Федулова Л. І. Технологічна модернізація промисловості України. К., 2008. 472 c.

4. Вітлінський В. В. Моделювання економіки: навч. посібник. К.: КНЕУ, 2003. $408 \mathrm{c}$.

5. Власов М. П., Шимко П. Д. Моделирование экономических процессов. Ростов н/Д: Феникс, 2005. 409 с.

6. Козина Л.Ф., Зеленцова Л. С. Проблемы социальноэкономического прогнозирования. Социальноэкономическое развитие г. Оренбурга: итоги, проблемы, перспективы: материалы науч.практич. конф. посвящ. 260-летию г. Оренбурга. Оренбург: ОГУ, 2003. С. 221-224.

7. Руська Р. В. Економетрика: навч. посібник. Тернопіль: Тайп, 2012. $224 \mathrm{c}$.

8. Офіційний сайт Державної служби статистики України. URL: http://www.ukrstat.gov.ua.

\section{References:}

1. Geyec V. M., Shinkaruk L. V., Artomova T. I. Strukturni zminy` ta ekonomichny`j rozvy` tok Ukrayiny`, K.: Ekspres, 2011, 696 s.

2. Kindzersky`j Yu. V. Promy`slovist` Ukrayiny`: strategiya i polity`ka strukturno-tehnologichnoyi modernizaciyi, K., 2013, 536 s.

3. Fedulova L. I. Tehnologichna modernizaciya promy`slovosti Ukrayiny`, K., 2008, 472 s.

4. Vitlinsky`j V. V. Modelyuvannya ekonomiky`: navch. posibny`k. K.: KNEU, 2003, 408 s.

5. Vlasov M. P., Shimko P. D. Modelirovanie ekonomicheskih processov. Rostov n/D: Feniks, 2005, 409 s.

6. Kozina L. F., Zelencova L. S. Problemy' social’no-ekonomicheskogo prognozirovaniya. Social 'no-ekonomicheskoe razvitie g. Orenburga: itogi, problemy`, perspektivy: materialy` nauch.praktich. konf. posvyash. 260-letiyu g. Orenburga. Orenburg: OGU, 2003, S. 221-224.

7. Ruska R. V. Ekonometrika: navch. posibnik. Ternopil: Tajp, 2012. 224 s.

8. Oficijnij sajt Derzhavnoyi sluzhbi statistiki Ukrayini. URL: http://www.ukrstat.gov.ua. 
The study of the country as a socio-economic system requires the study of its structural dynamics, the study of the processes of state regulation, as well as the analysis of the evolution of the sectoral structure, innovations.

The question remains as to the substantiation of a holistic indicator-factor system, which should be included in the economic-mathematical model of structural transformations of the country's economy, which can serve as an informational basis for making sound management decisions on the directions of structural changes in the economy.

The purpose of the study is to substantiate the modeling of the structural transformation of the country's economy in the face of globalization challenges.

Forecasting of branch structure on the basis of the index method is complicated, it is possible on the basis of mathematical modeling.

Consequently, the simulation allows an effective analysis of the situation and make an appropriate decision.

The article describes the basics of modeling of the structural transformation of the country's economy in the context of globalization challenges. A system of econometric models of the country's economy development based on the following types of economic activity: industry, agriculture, construction, transport, communications and services. The formation of a system of econometric models for each type of economic activity was carried out on the basis of data for 2001-2018 according to the following parameters: budget revenues of the country; investment in fixed assets; the volume of fixed assets in the field of production; number of employees; production of goods and services for the production industry.

On the basis of the system of econometric models of the country's economic development, the forecast of the structure of the economy for 2019-2022 was made. According to the results of the forecast values, an increase in the output of goods and services in market prices of indicators in 2022 is observed, compared with 2001, in general, by economy 17.3 times, industry - 13 times, agriculture - almost 15 times, construction - 16 times, transport and communications - 26.6 times, services -22.7 times.

On the basis of the obtained forecast values of output of goods and services in market prices by types of economic activity, the structure of the Ukrainian economy for 2001-2022 was presented. An assessment of the structural transformation was carried out and it was found that the sectoral structure of the Ukrainian economy has hardly changed and will not undergo significant changes in 2019-2022. The structural transformation took place in the Ukrainian economy in 2010, when there was a tendency to increase the share of gross output in the service sector.

The predicted structure of the country's economy allows developing state policy measures to stabilize the economy from the effects of a possible structural transformation.

Based on the forecast data of the structural transformation of the economic development model, the country is developing state policy measures to stabilize the economy from the effects of a possible structural transformation. The development of recommendations for stabilizing the economy from the effects of structural transformation and will be the subject of further research. 